\title{
PARASITISM BY VARROA AND Nosema sp. IN BEEHIVES USED FOR APPLE TREE POLLINATION ${ }^{1}$
}

\author{
LUCAS DE ALMEIDA BIZOTTO²*, REGIS SIVORI SILVA DOS SANTOS ${ }^{3}$, MARI INÊS CARISSIMI BOFF²
}

\begin{abstract}
The apple tree depends on cross-pollination for adequate fruiting. The objective of this study was to evaluate the rate of parasitism by Varroa destructor mites and the infection rate of Nosema sp. in hives of Apis mellifera (Linnaeus) used in pollinating services in apple orchards in the municipality of Vacaria, Rio Grande do Sul state, Brazil. The study evaluated the sanitation of beehives before, during, and after apple orchard pollination. Natural parasitism by $V$. destructor and the presence of Nosema sp. spores were evaluated in hives from areas of forest and canola cultivation (in the 2014/2015 harvest), and from areas of forest and eucalyptus reforestation (2015/2016 harvest). In both harvests, the average rate of parasitism in the hives by $V$. destructor ranged from 3.0 to $6.7 \%$. The levels of parasitism increased during the pollination period in hives from canola-cultivated areas (2014/2015 harvest), but not in those from the forest and eucalyptus reforestation areas. Spores of Nosema sp. were observed in hives in the 2014/2015 harvest but not in the 2015/2016 harvest. The levels of natural parasitism by $V$. destructor in A. mellifera hives used in pollination services remained low, and was within the levels reported for the southern region of Brazil. Additionally, the levels of Nosema sp. infection in the hives was low.
\end{abstract}

Keywords: Apis mellifera. Pollination. Apple trees. Health of hives.

\section{PARASITISMO POR VARROA E Nosema Sp. EM COLMEIAS DE ABELHAS UTILIZADAS NA POLINIZAÇÃO DE MACIEIRAS}

\begin{abstract}
RESUMO - A macieira é dependente da polinização cruzada para que haja a frutificação em níveis adequados. O presente estudo objetivou avaliar a intensidade natural de parasitismo por Varoa destructor e dos índices de infecção de Nosema sp. em colmeias de Apis mellifera (Linnaeus) utilizadas em serviços de polinização em pomar de macieiras no município de Vacaria, RS. O estudo abrangeu investigações de sanidade de colmeias antes, durante e após os serviços de polinização de pomares de macieiras. Foram realizadas avaliações de parasitismo natural por ácaros de $V$. destructor e presença de esporos de Nosema sp., em colmeias oriundas de áreas de mata e com cultivo de canola (safra 2014/15) e de matas e reflorestamento com eucaliptos (safra 2015/16). Em ambas as safras, as colmeias utilizadas apresentaram médias que variam de 3,0 a $6,7 \%$ de parasitismo por $V$. destructor. Houve aumento nos níveis de parasitismo no período da polinização, em colmeias oriundas de áreas de cultivo com canola (safra 2014/15), já colmeias oriundas de áreas de matas e reflorestamentos com eucaliptos não seguiram o mesmo comportamento. A presença de esporos de Nosema sp. foi constatada em colmeias utilizadas na safra de 2014/15, mas não ocorreu na safra de 2015/16. Os níveis de parasitismo natural por $V$. destructor em colmeias de $A$. mellifera utilizadas em serviços de polinização se mantiveram baixos, dentro dos níveis relatados para a região Sul do Brasil, já as infecções causadas por Nosema sp. se mostraram pouco expressivas para as colmeias avaliadas.
\end{abstract}

Palavras-chave: Apis mellifera. Polinização. Macieiras. Sanidade de colmeias.

\footnotetext{
${ }^{*}$ Corresponding author

${ }^{1}$ Received for publication in 08/04/2016; accepted in 07/18/2017.

Paper extracted from the Master dissertation of the first author.

${ }^{2}$ Departament of Agronomy, Universidade do Estado de Santa Catarina, Lages, SC, Brazil; bizottolucas@yahoo.com.br - ORCID: 00000002-6668-5781, mari.boff@udesc.br - ORCID: 0000-0003-1700-8837.

${ }^{3}$ Experimental station of temperate fruits, Embrapa Uva e Vinho, Vacaria, RS, Brazil; regis.sivori@embrapa.br - ORCID:0000-0001-68851627.
}

Rev. Caatinga, Mossoró, v. 31, n. 3, p. 773 - 778, jul. - set., 2018 


\section{INTRODUCTION}

Beekeeping has social, economic, and environmental importance. Because it requires low financial investment, this activity serves as an alternative source of income by the commercialization of bee products and the rental of beehives for pollination services. Hartfelder (2013) observed that, for beekeepers, the income from renting hives for pollination services is much higher than that obtained from honey production. The agroecosystem service provided by pollinating bees contributes directly to the production of food in terms of both quantity and quality. In monetary terms, apple tree cultivation in Brazil generates USD 440,800 annually (GIANNINI et al., 2015), and those authors reported that approximately $60 \%$ of this amount (USD 286,520,000) is generated by pollination services.

Apple tree cultivation is an agricultural activity that depends on cross-pollination for fruiting. For this purpose, pollinators such as insects are necessary for the transfer of pollen among compatible cultivars (PETRI et al., 2008). Apple orchids are self-incompatible and thus require crosspollination (GARRATT et al., 2014a). Despite the possibility of anemophilous pollination, wind pollination, and self-pollination in some apple variants, the production and quality of fruits in these cases are not sufficient, and the fruits do not meet the standards of size, fruiting, and productive potential. Garratt et al. (2014b) observed that proper pollination increased both seed quantity and the yield and quality of apple fruits.

Among the natural pollinators in apple orchards, bees of the species Apis mellifera Linnaeus, 1758 (Hymenoptera: Apidae) have been used successfully (SANTOS et al., 2013; SHEFFIELD, 2014). The possibility of $A$. mellifera maintenance in rational and populous beehives is an advantage, because it allows management techniques to be adopted and bees to be transported to orchards during the flowering period for pollination services (FREITAS; ALVES, 2008; PARK et al., 2010). However, recent studies have reported a decrease in the abundance of pollinators, including A. mellifera, indicating the need for further research on the subject (DEPRÁ et al., 2014).

The use of pesticides in apple orchards during the flowering period can induce stress in bees and lead to a loss of population in hives due to mortality, colony weakening (CHAMBÓ et al., 2010; FREITAS; PINHEIRO, 2010), and susceptibility to parasites (PETTIS et al., 2013). Among the parasites of $A$. mellifera, the mite Varroa destructor Anderson and Trueman, 2000 (Arachnida: Varroidae), known as varroa, is considered the most important bee pest worldwide because of its negative impact on hives (TURCATTO et al., 2012). In 2008, the microsporidium
(Dissociodihaplophasida: Nosematidae) destroyed several bee hives in the United States and Europe (WILLIAMS et al., 2011; MENDOZA et al., 2013). Previous studies found an association between the use of agrochemicals during the pollination period and the incidence of Nosema sp. in A. mellifera hives (PEGORARO et al., 2013; PETTIS et al., 2013).

The reduction of breeding areas and food reserves in the A. mellifera hives used for pollination services indicates physiological and behavioral changes that compromise the maintenance and development of hives (LEE et al., 2010). Data on the occurrence of $V$. destructor and Nosema sp., and the effect of these parasites on population variations in A. mellifera hives used in apple pollination in Brazil are limited. Therefore, the objective of this study was to evaluate the rate of parasitism by $V$. destructor and infection rates of Nosema sp. in $A$. mellifera beehives used in pollination services in apple orchards in the municipality of Vacaria, Rio Grande do Sul State (RS), Brazil.

\section{MATERIAL AND METHODS}

The study was conducted in two different commercial apple orchards containing the cultivars Royal Gala and Fuji Suprema located in the municipality of Vacaria, RS, from September 23, 2014 to December 10, 2014 (2014/2015 harvest) $\left(\mathrm{S} 28^{\circ} 25^{\prime} 40.50^{\prime \prime}\right.$ and $\left.\mathrm{W} 50^{\circ} 53^{\prime} 35.90^{\prime \prime}\right)$ and from September 2, 2015 to December 15, 2015 (2015/2016 harvest) (S28 36'45.55' and W50 53' $\left.31.96^{\prime \prime}\right)$. Forty beehives were used in each evaluation period ( 20 beehives in each orchard). Before being transported to the orchards, the bees foraged primarily in an area of forest and canola (Brassica napus L.) cultivation (2014/2015 harvest) and in an area of forest and eucalyptus (Eucalyptus sp.) reforestation (2015/2016 harvest). The forest areas used for the two harvests consisted of remnants of native fields and native forest. No management techniques were used for the breeding or selection of queens.

The beehives were labeled with Arabic numbers to identify the sites of origin. Four $A$. mellifera hives were used per hectare. The beehives were introduced in the orchards during the beginning of the flowering period (September) and were withdrawn at the end of the flowering period (second fortnight of October). The two orchards were managed using the integrated pest management (IPM) system. The application of insecticides to these orchards was interrupted during the apple blossom period. However, the application of fungicides was not interrupted. During the period of flowering and pollination, fungicides with the following active ingredients were applied in the 2014/2015 harvest: ethylene-bis-dithiocarbamate (Mancozeb), pyrimethanil, difenoconazole, 
dithianon, and propineb (four applications); whereas chlorothalonil, pyrimethanil, ethylene-bis-dithiocarbamate (Mancozeb), dithianon, fluazinam, difenoconazole, captan, and thiophanate methyl were applied in the 2015/2016 harvest (11 applications).

The presence of mites ( $V$. destructor) was evaluated in three distinct phases: 45 days before the removal of the hives for pollinating services (pre-pollination phase), at the end of the pollination service (exit of the apple orchard; pollination phase), and 45 days after the removal of the hives from the orchard (return of the hives to a new native forest area; post-pollination phase). For each assessment phase, 100-150 adult bees were collected in the breeding area of each hive. The bees were collected by passing a brush on the honeycomb and then transferred to plastic bottles containing $70 \%$ alcohol. In the laboratory, each bee was individually transferred to a test tube containing $70 \%$ alcohol. Subsequently, each test tube was manually shaken for 1 minute to release the mites. Then, the solution was poured into a $3.0-\mathrm{mm}$ sieve to allow the passage of alcohol and mites. The filtered solution was dried on filter paper to collect the mites, and the number of mites was counted using a stereomicroscope.

For the evaluation of nosemosis, 30 bees were collected in the breeding area of each hive. In the laboratory, the abdomen of each bee was detached using forceps, transferred to a crucible containing $35 \mathrm{ml}$ of distilled water, and homogenized by grinding. A 1-mL aliquot of the homogenate was poured onto a slide and observed under an optical microscope. When Nosema sp. was present, the solution was stirred and a 1-mL aliquot was transferred to a Neubauer chamber to quantify the number of spores per bees.

Data normality was analyzed by the Shapiro-Wilk test, and homoscedasticity was evaluated by the Hartley and Bartlett test. The means of each treatment were compared by Tukey's test using SASM-Agri software at a 5\% level of significance. The analyzed variables were the percentage of natural parasitism by $V$. destructor in A. mellifera hives during the study period.

\section{RESULTS AND DISCUSSION}

Mites were present in all hives through the study period, and the rate of parasitism in beehives from forest areas in the 2014/2015 and 2015/2016 harvests ranged from 0.6 to $13.9 \%$, and from 0.9 to $12.9 \%$, respectively. The rate of parasitism in hives from areas with canola cultivation or eucalyptus reforestation in the evaluated harvests varied from 0.75 to $14 \%$ and from 0.75 to $20 \%$, respectively.

Analysis of variance of the mean percentages of parasitism revealed that significant differences exist between beehives from areas with canola cultivation or eucalyptus reforestation (Table 1).

Table 1. Analysis of variance of Varroa destructor parasitism of Apis mellifera beehives used in the pollination of apple orchards in the city of Vacaria, Rio Grande do Sul, Brazil, in two consecutive harvests.

\begin{tabular}{|c|c|c|c|c|c|}
\hline Harvest/Source & Cause of variation & $\mathrm{DF}$ & $\mathrm{SS}$ & MS & F-test \\
\hline \multicolumn{6}{|l|}{$2014 / 2015$} \\
\hline \multirow{3}{*}{ Canola } & Treatments & 2 & 4.6633 & 2.3316 & $3.1907^{*}$ \\
\hline & Residue & 48 & 29.2262 & 0.6088 & \\
\hline & Total & 50 & 33.8896 & & \\
\hline \multirow{4}{*}{ Forest } & Treatments & 2 & 0.0121 & 0.0060 & $0.5013^{\mathrm{NS}}$ \\
\hline & Residue & 48 & 0.5794 & 0.0120 & \\
\hline & Total & 50 & 0.5915 & & \\
\hline & C.V. & & & & \\
\hline \multicolumn{6}{|l|}{ 2015/16 } \\
\hline & Treatments & 2 & 0.7392 & 0.3646 & $0.5013^{\mathrm{NS}}$ \\
\hline \multirow[t]{3}{*}{ Forest } & Residue & 30 & 25.5082 & 0.8502 & \\
\hline & Total & 32 & 23.5085 & & \\
\hline & Treatments & 2 & 6.8734 & 3.4367 & $3.2983^{*}$ \\
\hline \multirow[t]{3}{*}{ Eucalyptus } & Residue & 30 & 31.2583 & 1.4019 & \\
\hline & Total & 32 & 38.1317 & & \\
\hline & C.V. & & & & \\
\hline
\end{tabular}

Legends: DF, degrees of freedom; SS, sum of squares; MS, mean square; C.V, coefficient of variation; *Statistically significant; ${ }^{\mathrm{NS}}$ Not significant at a probability of $5 \%$ in the F-test.

In the beehives from forest areas, the average rate of parasitism in the pre-pollination and pollination periods was 3.3 and $3.2 \%$, respectively, and this increased to $4.0 \%$ after 45 days of leaving the orchards (post-pollination phase), without significant differences observed between the phases (Table 2). The rate of parasitism of the hives from canola cultivation was $3.4 \%$ in the pre-pollination period, which increased significantly to $5.6 \%$ during the pollination period, and decreased significantly to 
$3.3 \%$ after being removed from the orchards for 45 days (Table 2).

In the 2015/2016 harvest, the rate of parasitism in hives from the forest area was $3.4 \%$ in the pre-pollination period, which increased to $4.5 \%$ in the pollination phase, and $5.2 \%$ after 45 days of pollination, without significant differences between the three phases (Table 3). The average rate of parasitism in the hives from the area reforested with eucalyptus was significantly increased between the pre-pollination $(2 \%)$ and pollination $(7 \%)$ phases, and was non-significantly decreased to $5.4 \%$ after 45 days of leaving the orchard compared with the pre-pollination period (Table 2). This result is similar to that observed in hives from canola production areas in the 2014/2015 harvests (Table 2).

Table 2. Average percentage of parasitism by Varroa destructor in Apis mellifera hives used in the pollination of apple orchards in the city of Vacaria, Rio Grande do Sul, in three evaluation periods in the 2014/2015 harvest.

\begin{tabular}{lccc}
\hline \multirow{2}{*}{ Source } & \multicolumn{3}{c}{ Average \pm SE } \\
\cline { 2 - 4 } & Pre-pollination & Pollination & Post-pollination \\
\hline Forest & $3.3 \pm 1.04 \mathrm{a}$ & $3.2 \pm 0.86 \mathrm{a}$ & $4.0 \pm 0.82 \mathrm{a}$ \\
Canola & $3.4 \pm 1.00 \mathrm{~b}$ & $5.6 \pm 0.98 \mathrm{a}$ & $3.3 \pm 0.54 \mathrm{~b}$ \\
\hline
\end{tabular}

Means with the same letter in each row were not significantly different using Tukey test at a probability of $5 \%$.

Table 3. Average percentage parasitism by Varroa destructor in Apis mellifera hives used in the pollination of apple orchards in the municipality of Vacaria, Rio Grande do Sul, during three evaluation periods in the 2015/2016 harvests.

\begin{tabular}{lccc}
\hline \multirow{2}{*}{ Source } & \multicolumn{3}{c}{ Average \pm SE } \\
\cline { 2 - 4 } & Pre-pollination & Pollination & Post-pollination \\
\hline Forest & $3.4 \pm 0.68 \mathrm{a}$ & $4.5 \pm 0.73 \mathrm{a}$ & $5.2 \pm 1.43 \mathrm{a}$ \\
Eucalipto & $2.0 \pm 1.00 \mathrm{~b}$ & $7.0 \pm 1.94 \mathrm{a}$ & $5.4 \pm 2.54 \mathrm{ab}$ \\
\hline
\end{tabular}

Means with the same letter in each row were not significantly different using Tukey test at a probability of $5 \%$.

The increased parasitism of beehives by mites may be associated with the greater availability of floral resources at the beginning of spring. The beginning of flowering in natural vegetation and apple trees increases the supply of resources and consequently increases egg laying by the queens and the breeding area of the swarm (MESSAGE; GONÇALVES, 1995; PEGORARO et al., 2013). The increased number of pupae is related to the increased incidence of $V$. destructor (PICCIRILLO; DE JONG, 2003; MESSAGE; GONÇALVES, 1995). This is due to the interaction between feeding bees and the offspring during swarm foraging, which facilitates the movement of $V$. destructor females through the hive (LEE et al., 2010). The circulation of adult bees favors the spread of $V$. destructor from one area to another within the hive. In addition, the breeding areas of a beehive are obligatory sites for the reproduction of $V$. destructor because the offspring are the food source for the immature and male adult stages of this mite species. In addition, a strong negative correlation has been reported between varroa parasitism and the number of nesting areas in A. mellifera hives (PEGORARO et al., 2013). This characteristic is related to the subsequent increase in the number of adult bees present in the hives, which decreases the relative percentage of the mites (PEGORARO et al., 2013).

The significant increase in the $V$. destructor population can also be explained by swarming (in beehives from the canola cultivation area in the 2014/2015 harvest) observed after the transfer of the hives to the orchard, which reduced the number of adult bees per hive and promoted the increase in the mite population. Santos et al. (2014) reported that a higher rate of parasitism by $V$. destructor was observed in weak colonies with a low number of adult bees. The reduced number of adult bees in hives may have increased the relative percentage of the mite population and the consequent increase in the level of parasitism. In addition, the parasitism of operculated offspring (not evaluated in the present study) may have increased the percentage of $V$. destructor in bees that remained in the hive.

Considering that the apple tree flowering period is critical for the establishment of phytosanitary diseases, especially Venturia inaequalis (Cooke) Winter (FIORAVANÇO et al., 2010), the application of fungicides to control this disease in the flowering period is common (BONETI; KATSURAYAMA; SANHUEZA, 2006). During the flowering and pollination periods in the 2014/2015 harvest, the fungicides Mancozeb, pyrimethanil, difenoconazole, dithianon, and propineb were applied four times, whereas in the 2015/16 harvest, the fungicides chlorothalonil, pyrimethanil, Mancozeb, dithianon, fluazinam, difenoconazole, captan, and thiophanate methyl were applied 11 times.

Studies conducted in North America have 
shown that pollen contaminated with fungicides could increase the mortality of immature bees, resulting in weaker swarm colonies after their stay in the orchard (PETTIS et al., 2013). Pettis et al. (2013) observed that the collection of fungicide-contaminated pollen by bees might compromise the action of enzymes and micro-organisms responsible for the fermentation and transformation of pollen into bee bread. This factor may compromise the nutritional quality of the food resource and consequently reduce the immunity of bees, favoring the action and proliferation of $V$. destructor and the microsporidium Nosema $\mathrm{sp.}$

In addition, oscillations in the populations of $V$. destructor may be related to the genetic heterogeneity of hives used in pollination services. This may explain the strong variations observed in the present study, because there may be some degree of genetic resistance of bee populations to the mites. All evaluated colonies contained fertilized queens, which may have conferred varying degrees of resistance to the parasite. As infestation of bee colonies by mites depends on the genetic resistance of the bee population (MESSAGE; GONÇALVES, 1995), and the high genetic variability found in Africanized hybrids may also have contributed to the parasitism levels by $V$. destructor observed in the present study (TORRES; BARETO, 2013).

In conclusion, thus our results indicate that the permanence of hives in apple orchards for pollination services together with other factors, including the source, genetics, and population of the bees, affects the rate of parasitism by $V$. destructor.

The incidence of Nosema sp. was low and spores of the microsporidium were found only in two hives during the 2014/2015 harvest. The number of spores per bee ranged from 2,000 to 5,000. Clementino et al. (2016) explained that a severe infestation corresponds to more than 100,000 spores of Nosema sp. per bee, and this level of infestation was not observed in the present study. Therefore, for the evaluated hives, the presence of Nosema sp. was not considered a sanitary problem for the swarms used in the pollination of apple orchards.

\section{CONCLUSIONS}

For the bees used in the pollination of apple orchards in the municipality of Vacaria, RS, the average rates of parasitism by $V$. destructor varied and were similar to the levels reported in southern Brazil.

Significant increases in the rate of parasitism by $V$. destructor might occur during apple orchard pollination, but this increase was related to the site or origin of the hives before their transfer to the orchards.

Nosema sp. was present in the hives used in the pollination of apple orchards; however, the incidence was low.

\section{REFERENCES}

BONETI, J. I. S.; KATSURAYAMA, Y.; SANHUEZA, R. M. V. Características e controle da sarna na produção integrada de maçã. In: SANHUEZA, R. M. V.; PROTAS, J. F. S.; FREIRE, J. (Eds.). Manejo Integrado de macieira no sistema de produção integrada de frutas. Bento Gonçalves: Embrapa, 2006. v. 1, cap. 35, p. 33-49.

CHAMBÓ, E. D. et al. Aplicação de inseticida e seus impactos sobre a visitação de abelhas (Apis mellifera L.) no girassol (Helianthus annuus L.). Revista Brasileira de Agroecologia, Porto Alegre, v. 5, n. 1, p. 37-42, 2010.

CLEMENTINO, D. C. et al. Ocorrência da Nosemose em colônias de Apis mellifera $\mathbf{L}$. em apiário no município de Lagoa do Ouro, Microrregião de Garanhuns, Pernambuco. Disponível em: <http://www.cnpa2015.com.br/anais/ resumos/R0142-2.PDF>. Acesso em: 13 maio 2016.

DEPRÁ, M. S. et al. Pollination deficit in open-field tomato crops (Solanum lycopersicum L., Solanaceae) in Rio de Janeiro state, southeast Brazil. Journal of Pollination Ecology, Budapest, v. 12, n. 1, p. 1-8, 2014.

FIORAVANÇO, J. C. et al. Condições Meteorológicas e sua Influência na Safra de Maçã 2009/10 na Região de Vacaria, RS. Bento Gonçalves: EMBRAPA UVA E VINHO, 2010. 8 p. (Comunicado Técnico, 100).

FREITAS, B. M.; ALVES, J. E. Efeito do número de visitas florais da abelha melífera (Apis mellifera L.) na polinização da goiabeira (Psidium guajava L.) cv. Paluma. Revista Ciência Agronômica, Fortaleza, v. 39, n. 1, p. 148-154, 2008.

FREITAS, B. M.; PINHEIRO, J. N. Efeitos subletais dos pesticidas agrícolas e seus impactos no manejo de polinizadores dos agroecossistemas brasileiros. Oecologia Australis, Rio de Janeiro, v. 14, n. 1, p. 282-298, 2010

GARRATT, M. P. D. et al. Avoiding a bad apple: Insect pollination enhances fruit quality and economic value. Agriculture, Ecosystems and Environment, Histon, v. 184, n. 3, p. 3 4-40, 2014a.

GARRATT, M. P. D. et al. Pollination Deficits In Uk Apple Orchards. Journal of Pollination Ecology, Budapest, v. 12, n. 2, p. 9-14, 2014b.

GIANNINI, T. C. et al. The Dependence of Crops 
for Pollinators and the Economic Value of Pollination in Brazil. Journal of Economic Entomology, Annapolis, v. 1, n. 3, p. 1-9, 2015.

HARTFELDER, K. Polinizadores do Brasil. Revista Estudos Avançados, São Paulo, v. 27, n. 78, p. 303306, 2013.

LEE, K. V. et al. Practical sampling plans for Varroa destructor (Acari: Varroidae) in Apis mellifera (Hymenoptera: Apidae) colonies and apiaries. Journal of Economic Entomology, Annapolis, v. 103, n. 4, p. 1039-1050, 2010.

MENDOZA, Y. et al. Nosema ceranae and RNA viruses in European and Africanized honeybee colonies (Apis mellifera) in Uruguay. Apidologie, Springer-Verlag, Paris, v. 45, n. 2, p. 224-234, 2013.

MESSAGE, D.; GONÇALVES, L. S. Effect of the size of worker brood cells of Africanized honey bees on infestation and reproduction of the ectoparasitic mite Varroa jacobsoni Oud. Apidologie, Paris, v. 26, n. 5, p. 381-386, 1995.

PARK, M. G. et al. The role of native bees in apple pollination. Archives of Veterinary Science, Curitiba, v. 5, n. 1, p. 89-93, 2010.

PEGORARO, A. et al. Perdas de colônias de Apis mellifera L. no inverno suplementadas com alimentação artificial com pólen e favos de mel. Revista Agrarian, Dourados, v. 6, n. 19, p. 67-74, 2013.

PETRI, J. L. et al. Fenologia de espécies silvestres de macieiras como polinizadoras das cultivares Gala e Fuji. Revista Brasileira de Fruticultura, Jaboticabal, v. 30, n. 4, p. 868-874, 2008.

PETTIS, J. S. et al. Crop Pollination Exposes Honey Bees to Pesticides Which Alters Their Susceptibility to the Gut Pathogen Nosema ceranae. PloS ONE, California, v. 8, n. 7, p. 1-9, 2013.

PICCIRILLO, G. A.; DE JONG, D. The influence of brood comb cell size on the reproductive behavior of the ectoparasitic mite Varroa destructor in Africanized honeybee colonies. Genetic and Molecular Research, Ribeirão Preto, v. 2, n. 1, p. 36 $-42,2003$.

SANTOS, R. S. S. et al. Visita floral de Apis mellifera L. em diferentes clones de cultivares de maçãs Gala e Fuji e sua relação com variáveis meteorológicas em Vacaria, RS, Brasil. Revista de la Facultad de Agronomia, La Platana, v. 112, n. 2, p. 114-122, 2013.
SANTOS, L. G. et al. Honey Bee Health in Apiaries in the Vale do Paraíba, São Paulo State, Southeastern Brazil. Sociobiology, Feira de Santana, v. 61, n. 3, p. 307-312, 2014.

SHEFFIELD, C. S. Pollination, seed set and fruit quality in apple: studies with Osmia lignaria (Hymenoptera: Megachilidae) in the Annapolis valley, Nova Scotia, Canada. Journal of Pollination Ecology, Toronto, v. 12, n. 13, p. 120-128, 2014.

TORRES, R. N. S.; BARRETO, M. R. Incidência de Varroa destructor (Anderson \& Trueman) em Criação de Abelhas com Ferrão na Região de Sinop, Mato Grosso, Brasil. Entomo Brasilis, Vassouras, v. 6, n. 1, p. 30-33, 2013.

TURCATTO, A. P. et al. Infestação pelo Ácaro Varroa destructor (Anderson \& Trueman) (Mesostigmata: Varroidae) em operárias adultas e em células de cria de abelhas africanizadas Apis mellifera Linnaeus (Hymenoptera: Apidae) na região de Franca-SP. Entomo Brasilis, Vassouras, v. 5, n. 3, p. 198-203, 2012.

WILLIAMS, G. R. et al. The microsporidian Nosema ceranae, the antibiotic Fumagilin-B, and western honey bee (Apis mellifera) colony strength; Apidologie, Paris, v. 42, n. 10, p. 12-22, 2011. 